\title{
Public Expenditure, Public Sector Size and Growth: The European Union Marked Structural Differences
}

\author{
Angeliki Tsouhlou \\ Ministry of Finance \\ 10, Laskou str., 18536, Piraeus, Greece \\ E-mail: atsouhl@hotmail.com \\ John Mylonakis \\ 10, Nikiforou str., Glyfada \\ 16675, Athens, Greece \\ E-mail: imylonakis@vodafone.net.gr
}

Received: August 26, 2011

doi:10.5539/res.v3n2p33
Accepted: September 28, $2011 \quad$ Published: December 1, 2011

URL: http://dx.doi.org/10.5539/res.v3n2p33

\begin{abstract}
The scope of this paper is to examine the evolution of public expenditure and its structure per individual European Union (EU) member state, as well as, its potential correlation with the levels of economic prosperity (change of GDP) during the 1996-2007 period. The statistical data used for comparison have been taken from the European Statistical Service (Eurostat). Results showed that the majority of EU member states have a medium-sized public sector, while, irrespective of that size, all countries reduced the size of their public sectors. The average rate of growth in countries with large public sectors ranged between 1.4 and 3\%. In countries with medium-sized public sectors the rate of growth ranged from 1.5 to $4.6 \%$ while in countries with small public sectors it ranged between 3 to $7 \%$.
\end{abstract}

Keywords: Public services, Public expenditure, Public sector size, Government expenditure and revenue, Growth

\section{Introduction}

The quality and role played by government policy, which is typically measured by the size of public expenditure and the structure thereof, affects the economic development and well-being of those citizens whose indices comprise the GDP rate of change and/or the per capita income. Other economic values affected by public expenditure and government policy include inflation, savings, investments and unemployment.

At the same time, a society's future ability is also affected by its government's financial liabilities, the interest rates, as well as, certain social indices, such as health and education. Fair distribution of income and social stability are also indicative of a state's prosperity. Administrative and regulatory effectiveness, environmental protection and economic freedom are also considered as important priorities of a government's public policy (Newson, 2009; Remond-Tiedrez, 2009; Revelin, 2004).

The scope of this paper is to examine the evolution of public expenditure and its structure per individual European Union (EU) member state, as well as, its potential correlation with the levels of economic prosperity (change of GDP) during the 1996-2007 period. This review is considered important as it gives an overall view and perspective of the EU-27 member countries' economies and their public sector size taking into account the established 10 public expenditure categories.

The structure of public expenditure is based on the Classification of Function of Government (COFOG), developed by the Organization of Economic Cooperation and Development (OECD). This classification is considered as the most suitable for studying the structure of public expenditure and is implemented by the Eurostat (Pulpanova, 2005). The statistical data used for comparison have been taken from the European Statistical Service (Eurostat). 
The ten primary categories of public expenditure examined are: general public services, defence, public order and safety, economic affairs, environmental protection, housing and municipal benefits, health, cultural and religious programs, education, social protection and environmental protection expenditures (Villaume et al, 2008).

\section{Total European Union (EU) Public Expenditure}

The total public expenditure values of EU member states as a percentage of the GDP for the $1996-2007$ period are shown in the Table 1. EU countries are assigned into three different groups based on the total public expenditure of their general government, expressed as a percentage of the GDP for year 2007, as follows: large public sector when public expenditure as a percentage of the GDP exceeds $50 \%$, medium-sized public sector when public expenditure as a percentage of the GDP ranges between $40-50 \%$, and small public sector when public expenditure as a percentage of the GDP is below $40 \%$. The majority of member states fall within the medium-sized public sector group. Three countries (Sweden, France and Denmark) have large public sectors, sixteen countries have medium-sized public sectors and eight countries have small public sectors (Pulpanova, 2004/2005/2006).

Seven countries were assigned to the first group (large public sector) in 1996: Sweden, Finland, Austria, Denmark, France, Italy and Belgium. These countries reduced the size of their public sectors in the course of the 1996 - 2007 period. However, it has been observed that countries such as Sweden, France and Denmark have maintained their levels of total public expenditure at over $50 \%$ of the GDP, despite a fall of nearly 10 percentage points achieved in Sweden, 8 percentage points in Denmark and almost 3 percentage points in France. More specifically, in the case of Sweden, the total public expenditure for the above-mentioned period ranged between $63 \%$ and $52.5 \%$ of the GDP (Biedma, 2005; Jablonska, 2005; Paternoster et al, 2008).

On the other hand, one can find the countries of Eastern Europe (Estonia, Latvia, Lithuania, Romania, Slovakia), as well as, Ireland, Spain and Luxembourg (Tokofai, 2008). The public expenditure of these countries ranges from $41.8 \%$ to $31.5 \%$. Overall, the levels of public expenditure within the Europe of the 27 for the $2002-2006$ time period range between $46.8 \%-47.5 \%$ of the GDP (Table 1 ).

It is also remarked that the expenditure of those countries that significantly exceeded $50 \%$ of the GDP until year 2000, entered a phase of decline from that year onwards (Tokofai, 2009). More specifically, Belgium and Finland ended up in scores of $48.4 \%$ or $47.3 \%$ respectively, following extensive variations during the course of these 12 years. Italy followed a more stable course maintaining its public expenditure between $52.5 \%$ and $46.2 \%$, allowing only slight deviations (either positive or negative) from allocating half of its GDP to cover public expenditure (Table 1).

\subsection{General public services}

This group includes expenditure incurred in favour of executive and legislative bodies, expenses related to the operation and management of finances by the Ministry of Finance (fiscal, customs, tax, and controlling services), management of public resources, public debt management and service, statistical services, operation and management of services relating to the Ministry of Foreign Affairs (including diplomatic services, embassy affairs, representation and participation in international organisations), external financial support (with the exception of military aid and support towards peace organisations), operation and management of financial and social planning services, operation and management of staffing services (including staff selection, promotion and evaluation procedures, as well as, position evaluation and classification, etc.), procurement, maintenance ad repair of public facilities, administrative and operational costs and all kinds of benefits in favour of public or non-public organisations (research institutes, universities) that engage in research, transfer payments, election expenses, research expenses, and other central services expenditure that cannot be assigned to another category.

The funds of EU member states devoted to covering general public expenditure, expressed as percentage of the GDP vary (Table 2). The several member states present significant variations in this regard. The general public services expenditure for countries with large public sectors ranges from $6.0 \%$ to $11.0 \%$ of the GDP, while for countries with small public sectors it represents $2.9 \%$ to $7.6 \%$ of the GDP. A characteristic case is that of Italy and Greece, two countries which maintain comparatively high numbers during the course of the 12-year period: $14.1 \%$ to $8.6 \%$ and $14.0 \%$ to $8.0 \%$ respectively. In general terms, all states have progressively reduced their expenditure during 1996 - 2007 (Jablonska, 2006).

\subsection{Defence expenditure}

Defence expenditure includes the following: military expenses by all three law enforcement bodies, law enforcement expenses, external military aid, research and development expenses for national defence, as well as 
grants and loans/ benefits to non governmental organisations and universities with the aim to promote research in the field of defence.

Defence expenditure for the EU-27 in 2007 amounts to $1.5 \%$ of the GDP (Table 3). The country with the highest expenditure in this category was Greece, with its defence expenditure ranging from 1.9\% to 4.0\% of the GDP during the 1996 - 2007 period. More specifically for the years $1996-1998$ and for the year 2006, the defence expenditure of the United Kingdom was higher than that of Greece: $2.8 \%-2.6 \%$ of the GDP in the respective years (Pulpanova, 2005/2006). The countries reporting the lowest defence expenditure scores were Luxembourg $(0.2 \%-0.6 \%)$ and Ireland $(0.5 \%-0.9 \%)$.

\subsection{Economic affairs expenditure}

This category includes the following: general expenditure for managing finances, commercial affairs (planning and implementation of economic and commercial policies, import-export support programmes, patents and intellectual property rights, etc.), and employment affairs (planning and implementation of employment policies, employment supervision and regulation, employment programmes support and management, etc.). It also includes expenses in the rural sector (agriculture - forests - fisheries, land remediation projects, agricultural loans and subsidies, market regulations for agricultural - forestry - fishery products, etc.), energy expenses (industry, electrical energy, oil products, atomic energy, metallurgy, loans and subsidies in the field of energy, processing, manufacturing), transport expenses (road - water - rail - air transport) and communications, tourist expenses, as well as, expenses relating to the R\&D programmes for all the above sectors.

This type of expenditure for the EU-27 amounted in 2007 to 3.9\%. Significant differences were observed among various countries and between years during 1996 - 2007. As far as the EU-15 is concerned, the above type of expenditure ranged between $3.6 \%$ and $3.9 \%$ (Table 4 ).

For member states in particular, this category of expenditure ranges between $2.7 \%$ and $7.1 \%$ of the GDP. The United Kingdom and France steadily maintain low levels, while Czech and Malta present high scores. The great difference observed between Czech and Malta data is due to the fact that this expenditure category includes entries on transactions related to transfers performed by the general government towards businesses or other legal entities not classified under the general government (Gagel, 2008a and 2008b).

\subsection{Health expenditure}

This category includes expenses relating to the provision of health care, either on an individual or collective basis. More specifically, it includes expenses on medical products, medical devices and equipment, hospital services, public health services, external patient care and research \& development in the health sector.

This constitutes the second largest category after social protection, representing $6.6 \%$ of the GDP for the EU-27 in year 2007. The data available on EU-15 and the Eurozone during the $2000-2004$ period indicate a stable raise in this category of expenditure. In 2007, the highest level of expenditure as a percentage of the GDP was that of Austria and the United Kingdom with 7.5\%, followed by Denmark, France and Czech with 7.3\%, 7.2\% and $7.1 \%$ respectively. The lowest levels were those of Cyprus 2.9\%, Bulgaria 3.1\% and Romania 4.3\% (Table 5).

With regard to Sweden and Denmark, being countries with large public sectors, these maintained their health expenditure levels despite the decline in the size of their public sectors by 10 and 8 points respectively. Finland and Austria, with medium-sized public sectors and having reduced their size to a great extent, maintained high levels of health expenditure with 6.6\% and 7.3\% respectively (Borges, 2004). Those countries with small public sectors did not produce any significant variations between 1996 and 2007, and reported health expenditure scores of approximately 5\% of their GDP (Table 5).

\subsection{Education expenditure}

This category includes official education (pre-primary, primary, secondary, higher, vocational training institutes), training that does not fall within a specific level, as well as, supplementary services relating to education. This category also includes research \& development programmes in this field. It should be pointed out that, as happens with almost every category of expenses based on the COFOG classification, countries face difficulties distinguishing R\&D expenses in this category from the respective expenses of other categories (Schmidt, 2003).

EU-15 expenditure increased from 5\% in 2000 to $5.3 \%$ in 2004, while for the EU-27 the respective expenditure reaches 5.1\% in 2007 (Andren and Schmidt, 2005; Reis, 2008). The highest expense numbers were recorded by Denmark, Sweden, Portugal and Estonia, while the lowest were recoded by Germany, Romania, Slovakia, Ireland and Spain. Greece is seen at the bottom part of the list (Table 6). Countries like Sweden and Denmark, 
the public sector size of which has fallen by nearly 10 and 8 percentage points, respectively, have maintained their highest scores of approximately 7\% (de Norre and Baert, 2009).

\subsection{Social protection expenditure}

This category includes expenses relating to the provision of services or the payment of pensions - benefits (old age, disease, disability, marital status, unemployment, residence, social exclusion, etc.) on both an individual and collective basis. This category also includes the cost of research \& development programmes in this sector. These expenses represent by far the largest part of total expenditure in all country groups as compared with the remaining categories; namely the percentage is over two times above.

The majority of member states have reduced their social protection expenditure, yet such reduction was relatively lower than the extent of reduction of their public sector size (Petrasova, 2006/2007/2008; Puglia, 2011). Those countries with a small public sector have recorded the lowest percentages of social protection expenditure as compared with the remaining countries, in the social protection category (Abramovici, 2003/2004; Gagel, 2008a; Mattonetti, 2009).

During 2000 - 2004, most countries have recorded increase of their social protection expenditure. The countries with large public sectors have reported the highest expenditure of $22 \%$ of their respective GDP (Abramovici, 2002a, 2002b; Gagel, 2008b). The countries with the highest scores in this category are Sweden, France and Denmark (Table 7), while the ones with the lowest are the countries of Eastern Europe (Estonia, Latvia, Lithuania, Cyprus and Romania).

\subsection{Public order and safety expenditure}

This category includes expenses for police and fire services, prison management, operation and support, courts, as well as R\&D programmes within the scope of public order and safety.

Public Order and Safety Expenditure reached an average of 1.8\% for EU-27 in 2007 (Table 8), varying from $2.5 \%$ in the United Kingdom and $3.1 \%$ in Bulgaria (highest recorded percentages) to $1 \%$ and $0.9 \%$ in Denmark and Luxembourg (lowest recorded percentages). This category is characterised by variations to such an extent that make it impossible to draw conclusions on countries with small or large public sectors (Tokofai, 2008, 2009).

\subsection{Housing and community amenities expenditure}

The expenses included in this category relate to housing, water supply, municipal development and street illumination, and amounted to approximately 1\% of the GDP for the EU-27 in 2007 (Table 9). These form the second lowest type of expenditure following environmental protection. Cyprus was the one to report the highest percentage of expenditure in this category with $2.5 \%$ of the GDP in 2006 , followed by France with $1.9 \%$ and Ireland with $2.0 \%$. The lowest percentage was reported by Lithuania ( $0.3 \%$ of the GDP), along with Belgium, Greece and Finland $(0.4 \%$ of the GDP).

The variations over years and countries are due to the transactions entered by the various countries in this category. For example, Italy has reduced the amounts provisioned under this category through securitisation. It should be noted that the provision of housing benefits to households is not recorded under this category, but rather under the social protection category (Svennebye, 2008).

\subsection{Recreation, culture and religion expenditure}

Recreation, culture and religion expenditure includes all operating expenses for recreation, cultural and sports services, radio and television transmissions, printed publications, as well as, the management of religious and other municipal services.

This category of expenditure for the EU-27 represented an average of 1.1\% of the GDP for 2007 (Table 10). During 1996 - 2007, the highest number in this category was recorded by Luxembourg and Estonia, while the lowest was recorded by Greece. Low percentages were also reported in Ireland ( $0.4 \%$ in 1997 and $0.7 \%$ in 2007), as well as in Germany (0.7\%), which were comparatively lower than the EU-27 average (Tavares and Thomas, 2008a, b).

\subsection{Environmental protection expenditure}

This category includes the following expenditure: management and operation of the waste administrative system, including the nuclear waste, collection - processing - disposal of waste, collection and recycling of water, drainage system expenses, environmental pollution suppression, biodiversity protection costs and landscape protection in general, as well as, any related $R \& D$ programme expenses. 
The levels of expenditure falling under this category are lower in percentage compared with the other COFOG classification categories, reaching an average of $0.7 \%$ for the EU-27 in 2007 (Table 11). Yet, it is commonly known that the respective numbers entered for several countries are underestimated, due to the fact that several difficulties were encountered in measuring environmental expenditure by the data source (Olsson, 2005). Luxembourg, Czech, Bulgaria, the United Kingdom and Malta reported the highest numbers $(1.0 \%, 1.0 \%, 1.4 \%$, $1.0 \%$ and $1.5 \%$ of the GDP, respectively for 2007), while Finland and Cyprus (0.3\%) reported the lowest (Georgescu and Cabeca, 2010).

\section{Growth differences in the $\mathrm{EU}$}

The average rate of growth in countries with large public sectors during the 1996-2007 period ranged between $1.4 \%$ (Italy) and 3\% (Sweden). In countries with medium-sized public sectors, the rate of growth ranged from $1.5 \%$ and $1.7 \%$ (Germany, Malta) to $4.6 \%$ (Poland) and $4.3 \%$ (Slovenia). In countries with small public sectors, the rate of growth recorded was between 3\% (Romania, Bulgaria) and 7\% (Ireland, Estonia and Latvia). It is observed that the countries with small public sectors recorded the highest growth rates, followed by countries with medium-sized and large public sectors (Kostadinova et al, 2011; Svennebye, 2008).

The countries with the highest reductions in the size of their public sectors, such as Slovakia, Finland, Sweden, Poland and Austria maintained satisfactory growth rates (Kruger, 2007). Slovakia, with a reduction of 17 points, presented a growth rate of $5 \%$, while Sweden, with a reduction of $10 \%$, maintained a steady growth during the 1996-2007 period, with an average of 3\%. Finland, with a respective reduction percentage of 12 points, recorded an average growth rate of $3.8 \%$. Poland, with a reduction percentage of $9 \%$, recorded a high growth rate of $4.6 \%$, while Denmark and Austria, with reductions by $8 \%$, recorded lower growth rates of $2 \%$ and $2.5 \%$ (Table 12 ). This means that four countries characterised by significant reductions in the size of their public sectors exceeding 10 points have nonetheless maintained growth rates ranging from $3 \%$ to $5 \%$.

\section{Conclusions}

The majority of EU member states have a medium-sized public sector, while, irrespective of that size, all countries reduced the size of their public sectors. The countries with smaller public sectors recorded the highest growth rates, followed by countries with medium-sized and large public sectors. Four countries characterised by significant reductions in the size of their public sectors exceeding 10 points have nonetheless maintained satisfactory growth rates ranging from $3 \%$ to $5 \%$.

The majority of member states reduced the amount of social protection expenditure, which also represents the largest part of public expenditure, yet such reduction was to a proportionally less extent than the extent of reduction of their public sectors. Moreover, the countries with small public sectors recorded the lowest percentages for social protection public expenditure.

The countries with large public sectors maintained their health expenditure percentages despite the reduction in the size of public sectors in two cases by 10 and 8 points (in Sweden and Denmark, respectively). Countries like Sweden and Denmark, the public sector size of which has fallen by nearly 10 and 8 percentage points respectively, have maintained their highest scores in education expenditure of approximately $7 \%$, while Italy recorded the lowest score of $4.5 \%$.

Despite reduction in public sector sizes, the countries with medium-sized public sectors have not presented any significant deviations in education expenditure between the years 1996 and 2007. In conclusion, the countries of the EU during the course of the 1996-2007 decade have reduced the size of their public sectors without indications of undermining their growth.

The paper is based on data published by Eurostat from 1996 to 2007 comparing the various public sector expenditure categories. Further study is needed to explore deeply their possible relationship with growth using different statistical tests. Also, more historical and updated data are needed for specific countries in order to produce a comprehensive and complete study of the status of the EU-27 member states' public expenditure.

\section{References}

Abramovici, G. (2002a). Social protection in Europe. Eurostat, Population and Social conditions, Statistics in focus, Theme 3-1, 1-6.

Abramovici, G. (2002b). Social protection: expenditure on pensions. Eurostat, Population and Social conditions, Statistics in focus, Theme 3-6, 1-5.

Abramovici, G. (2003). The Social Protection in Europe. Eurostat, Population and Social conditions, Statistics in focus, Theme 3-3, 1-6. 
Abramovici, G. (2004). Social Protection in Europe. Eurostat, Population and Social conditions, Statistics in focus, Theme 3-6, 1-6.

Andren, B. and Schmidt, P. (2005). Education in Europe Key Statistics 2002-2003. Eurostat, Population and Social conditions, Statistics in focus, No 14, 1-7.

Biedma, L. (2005). Gross Domestic Product 2003. Eurostat, Economy and Finance, Statistics in focus, No 8 , $1-7$.

Borges, P. (2004). General government expenditure and revenue in the EU in 2003. Eurostat, Economy and Finance, Statistics in focus, No 41, 1-6.

Gagel, S. (2008a). Expenditure on Labour Market Policies, 2005. Eurostat, Population and Social conditions, Statistics in focus, No 45.

Gagel, S. (2008b). Nearly 2\% of EU-27 GDP spent on labour market policies in 2006. Eurostat, Population and Social conditions, Statistics in focus, No 94.

Georgescu, M.A. and Cabeca, J.C. (2010). Environment protection expenditure accounted for $1.8 \%$ of EU25 GDP in 2006. Eurostat, Environment and Energy, Statistics in focus, No 31.

Jablonska, I. (2005). General government expenditure and revenue in the EU in 2004. Eurostat, Economy and Finance, Statistics in focus, No 24, 1-6.

Jablonska, I. (2006). General government expenditure and revenue: 2005 data. Eurostat, Economy and Finance, Statistics in focus, No 19, 1-6.

Kostadinova, I., Stanislav, E. and Tokofai, A. (2011). EU27 and area government expenditure-to-GDP ratios falling after 10 quarters of growth. Eurostat, Economy and Finance, Statistics in focus, No 13.

Kruger, A. (2007). Regional Gross Domestic Product in the European Union 2004. Eurostat, General and Regional Statistics, Economy and Finance, Statistics in focus, No 104.

Mattonetti, M.L. (2009). Net expenditure on social protection benefits. Eurostat, Population and Social conditions, Statistics in focus, No 102.

Newson, B. (2009). Recession in the EU-27: length and depth of the down turn varies across activities and countries. Eurostat, Industry, Trade and Services, Statistics in focus, No 97.

Norre, de B. and Baert, K. (2009). Perception of health and access to health care in the EU-25 in 2007. Eurostat, Population and Social conditions, Statistics in focus, No 24.

Olsson, N. (2005). Environment Protection Expenditure in Europe by public sector and specialized producers 1995-2002. Eurostat, Environment and Energy, Statistics in focus, No 10, 1-9.

Paternoster, A., Wozowczyk, M. and Lupi, A. (2008). General government expenditure and revenue in the EU, 2006. Eurostat, Economy and Finance, Statistics in focus, No 23, 1-11.

Petrasova, A. (2006). Social protection in the European Union. Eurostat, Population and Social conditions, Statistics in focus, No 14, 1-9.

Petrasova, A. (2007). Social protection in the European Union. Eurostat, Population and Social conditions, Statistics in focus, No 99, 1-9.

Petrasova, A. (2008). Social Protection in the European Union. Eurostat, Population and Social conditions, Statistics in focus, No 46.

Puglia, A. (2009). In 2006 gross expenditure on social protection accounted for 26.9\% of GDP in the EU-27. Eurostat, Population and Social conditions, Statistics in focus, No 40.

Puglia, A. (2011). In 2008 gross expenditure on social protection in EU-27 accounted for 26.4\% of GDP. Eurostat, Population and Social conditions, Statistics in focus, No 17.

Pulpanova, L. (2004). Trends in selected government expenditure by function of EU Member States. Eurostat, Economy and Finance, Statistics in focus, No 43, 1-5.

Pulpanova, L. (2005). General government expenditure by function in the EU in 2003. 2000-2004. Eurostat, Economy and Finance, Statistics in focus, No 28, 2-5.

Pulpanova, L. (2006). Trends in government expenditure by function, 2000-2004. Eurostat, Economy and Finance, Statistics in focus, No 11, 2. 
Reis, F. (2008). 5\% of EU GDP is spent by government on education. Eurostat, Population and Social conditions, Statistics in focus, No 117.

Remond-Tiedrez, I. (2009). Recession in the EU-27: output measures. Eurostat, Industry, Trade and Services, Statistics in focus, No 17.

Revelin, G. (2004). General government expenditure and revenue of EU Member States in 2002. Eurostat, Economy and Finance, Statistics in focus, Theme 2-4, 1-6.

Schmidt, P. (2003). Public expenditure on Education in the EU in 1999. Eurostat, Population and Social conditions, Statistics in focus, Theme 3-22, 1-6.

Svennebye, L. (2008). GDP per capita, consumption per capita and comparative price levels in Europe. Eurostat, Economy and Finance, Statistics in focus, No 3.

Tavares, C. and Thomas, G. (2008a). Crime and Criminal Justice. Eurostat, Population and Social conditions, Statistics in focus, No 19.

Tavares, C. and Thomas, G. (2008b). Crime and Criminal Justice. Eurostat, Population and Social conditions, Statistics in focus, No 15.

Tokofai, A. and Villaume, S. (2008). Government quarterly expenditure and revenue in the EU, fourth quarter 2007. Eurostat, Economy and Finance, Statistics in focus, No 54.

Tokofai, A. (2009). Government quarterly revenue and expenditure in the EU, Second quarter 2009. Eurostat, Economy and Finance, Statistics in focus, No 93.

Villaume, S., Tokofai, A. and Ahamdanech, Z. I. (2008). Quarterly Accounts for General Government. Eurostat, Economy and Finance, Statistics in focus, No 102 
Table 1. Public expenditure (\% of GDP)

\begin{tabular}{|c|c|c|c|c|c|c|c|c|c|c|c|c|}
\hline & 1996 & 1997 & 1998 & 1999 & 2000 & 2001 & 2002 & 2003 & 2004 & 2005 & 2006 & 2007 \\
\hline Austria & 55,9 & 53,7 & 54,0 & 53,7 & 52,1 & 51,6 & 51,0 & 51,5 & 54,0 & 49,8 & 49,4 & 48,4 \\
\hline Belgium & 52,4 & 51,1 & 50,4 & 50,2 & 49,2 & 49,2 & 49,9 & 51,2 & 49,4 & 52,1 & 48,4 & 48,4 \\
\hline Bulgaria & & & & & 42,6 & 40,3 & 40,3 & 40,3 & 39,7 & 39,3 & 36,5 & 41,5 \\
\hline France & 54,5 & 54,1 & 52,7 & 52,6 & 51,6 & 51,6 & 52,6 & 53,3 & 53,2 & 53,4 & 52,7 & 52,3 \\
\hline Germany & 49,3 & 48,4 & 48,0 & 48,1 & 45,1 & 47,6 & 48,1 & 48,5 & 47,1 & 46,8 & 45,3 & 44,2 \\
\hline Denmark & 58,8 & 56,6 & 56,2 & 55,4 & 53,6 & 54,2 & 54,6 & 55,1 & 54,6 & 52,8 & 51,6 & 51,0 \\
\hline Greece & 43,9 & 44,8 & 44,2 & 44,3 & 46,7 & 45,3 & 45,1 & 45,0 & 45,4 & 43,3 & 42,2 & 43,7 \\
\hline Estonia & 39,6 & 37,5 & 39,4 & 40,3 & 36,5 & 35,1 & 35,9 & 34,9 & 34,1 & 34,0 & 34,2 & 35,5 \\
\hline $\begin{array}{l}\text { United } \\
\text { Kingdom }\end{array}$ & 42,3 & 40,5 & 39,4 & 38,8 & 39,0 & 40,1 & 41,0 & 42,0 & 42,9 & 44,2 & 44,2 & 44,4 \\
\hline Ireland & 39,1 & 36,7 & 34,5 & 34,1 & 31,5 & 33,3 & 33,6 & 33,4 & 33,7 & 33,7 & 33,8 & 35,4 \\
\hline Spain & 43,2 & 41,6 & 41,1 & 39,9 & 39,1 & 38,6 & 38,9 & 38,4 & 38,9 & 38,4 & 38,5 & 38,8 \\
\hline Italy & 52,5 & 50,3 & 49,2 & 48,2 & 46,2 & 48,0 & 47,4 & 48,3 & 47,7 & 48,1 & 48,7 & 47,9 \\
\hline Cyprus & & & 36,7 & 36,8 & 37,0 & 38,2 & 40,2 & 45,0 & 42,8 & 43,6 & 43,4 & 42,9 \\
\hline Latvia & 36,9 & 36,3 & 40,2 & 41,8 & 37,3 & 34,6 & 35,6 & 34,8 & 35,8 & 35,6 & 37,9 & 35,5 \\
\hline Lithuania & & & & & 39,1 & 36,8 & 34,7 & 33,2 & 33,3 & 33,3 & 33,6 & 35,2 \\
\hline Luxembourg & 41,1 & 40,7 & 41,1 & 39,2 & 37,6 & 38,1 & 41,5 & 41,8 & 42,5 & 41,6 & 38,6 & 37,7 \\
\hline Malta & 42,6 & 42,9 & 43,0 & 43,0 & 41,0 & 43,1 & 43,2 & 47,8 & 45,5 & 44,6 & 43,4 & 41,9 \\
\hline Holland & 49,4 & 47,5 & 46,7 & 46,0 & 44,2 & 45,4 & 46,2 & 47,1 & 46,1 & 44,8 & 45,6 & 45,3 \\
\hline Hungary & & & & & & 47,4 & 51,4 & 49,1 & 48,9 & 50,1 & 51,9 & 49,7 \\
\hline Poland & & & & & & & 44,2 & 44,6 & 42,6 & 43,3 & 43,8 & 42,0 \\
\hline Portugal & 44,1 & 43,2 & 42,8 & 43,2 & 43,1 & 44,4 & 44,3 & 45,5 & 46,5 & 47,6 & 46,3 & 45,8 \\
\hline Romania & & & & & & & 35,0 & 33,5 & 33,5 & 33,5 & 35,3 & 36,6 \\
\hline Slovakia * & 53,7 & 49,0 & 45,8 & 47,9 & 50,9 & 44,6 & 45,1 & 40,1 & 37,7 & 38,1 & 37,1 & 34,6 \\
\hline Slovenia & & & & & 46,7 & 47,6 & 46,3 & 46,4 & 45,8 & 45,3 & 44,5 & 42,4 \\
\hline Sweden & 63,0 & 60,9 & 58,8 & 58,6 & 55,6 & 55,5 & 56,7 & 56,9 & 55,6 & 55,2 & 54,1 & 52,5 \\
\hline Czech Republic & 42,6 & 43,2 & 43,2 & 42,3 & 41,8 & 44,5 & 46,3 & 47,3 & 45,1 & 45,0 & 43,8 & 42,6 \\
\hline Finland & 59,9 & 56,2 & 52,6 & 51,5 & 48,3 & 47,8 & 48,8 & 50,1 & 50,1 & 50,3 & 48,7 & 47,3 \\
\hline EU - 27 & & & & & & & 46,7 & 47,3 & 46,9 & 46,9 & 46,3 & 45,8 \\
\hline
\end{tabular}

Source: Eurostat

* Estimations 
Table 2. General public services (\% of GDP)

\begin{tabular}{|c|c|c|c|c|c|c|c|c|c|c|c|c|}
\hline & 1996 & 1997 & 1998 & 1999 & 2000 & 2001 & 2002 & 2003 & 2004 & 2005 & 2006 & 2007 \\
\hline Austria & 8,6 & 8,1 & 8,2 & 8,0 & 7,9 & 7,9 & 7,6 & 7,0 & 7,0 & 6,9 & 7,0 & 6,9 \\
\hline Belgium & 12,2 & 11,5 & 11,0 & 10,7 & 10,5 & 10,4 & 10,1 & 9,8 & 9,3 & 9,1 & 8,4 & 8,5 \\
\hline Bulgaria & & & & & 8,4 & 8,5 & 6,5 & 3,5 & 5,6 & 5,5 & 4,5 & 8,2 \\
\hline France & 8,4 & 8,5 & 7,9 & 7,8 & 7,6 & 7,5 & 7,3 & 7,4 & 7,2 & 7,3 & 7,0 & 6,9 \\
\hline Germany & 6,7 & 6,6 & 6,7 & 6,5 & 6,0 & 5,8 & 5,8 & 5,9 & 5,7 & 5,7 & 5,6 & 5,5 \\
\hline Denmark & 10,0 & 9,3 & 9,1 & 8,6 & 8,0 & 7,9 & 7,6 & 7,2 & 6,9 & 6,3 & 6,1 & 6,0 \\
\hline Greece & 14,0 & 13,0 & 11,9 & 10,8 & 11,1 & 10,1 & 9,6 & 8,5 & 8,8 & 8,1 & 7,9 & 8,0 \\
\hline Estonia & 4,2 & 4,0 & 4,6 & 3,9 & 3,7 & 3,2 & 3,8 & 3,3 & 2,9 & 2,9 & 2,9 & 3,3 \\
\hline $\begin{array}{l}\text { United } \\
\text { Kingdom }\end{array}$ & 5,5 & 5,3 & 5,4 & 4,7 & 4,5 & 4,2 & 4,0 & 3,8 & 4,1 & 4,6 & 4,4 & 4,4 \\
\hline Ireland & 7,0 & 6,1 & 5,8 & 5,0 & 4,7 & 4,3 & 4,1 & 4,0 & 3,9 & 3,7 & 3,5 & 3,7 \\
\hline Spain & 7,5 & 7,1 & 6,7 & 6,0 & 5,6 & 5,5 & 5,3 & 5,1 & 4,8 & 4,7 & 4,6 & 4,5 \\
\hline Italy & 14,1 & 12,5 & 11,4 & 10,1 & 9,7 & 9,8 & 9,5 & 9,3 & 8,9 & 9,0 & 8,6 & 8,6 \\
\hline Cyprus & & & 8,8 & 8,7 & 8,8 & 9,0 & 9,2 & 10,4 & 9,6 & 10,1 & 9,9 & 10,2 \\
\hline Latvia & 6,8 & 6,8 & 8,0 & 6,4 & 6,1 & 4,9 & 5,2 & 5,5 & 6,4 & 7,1 & 7,6 & 3,8 \\
\hline Lithuania & & & & & 5,5 & 5,5 & 4,5 & 4,4 & 4,1 & 4,2 & 4,1 & 4,0 \\
\hline Luxembourg & 3,9 & 5,0 & 4,9 & 4,9 & 4,8 & 4,6 & 4,7 & 4,5 & 4,8 & 4,5 & 4,1 & 4,1 \\
\hline Malta & 5,2 & 5,4 & 5,5 & 6,1 & 6,6 & 6,3 & 6,3 & 6,3 & 7,5 & 6,7 & 6,6 & 6,3 \\
\hline Holland & 10,0 & 9,6 & 9,5 & 9,1 & 8,6 & 8,3 & 8,1 & 8,3 & 7,7 & 7,6 & 7,3 & 7,3 \\
\hline Hungary & & & & & & 10,5 & 9,8 & 8,9 & 9,3 & 9,3 & 9,6 & 9,3 \\
\hline Poland & & & & & & & 6,0 & 6,3 & 6,3 & 6,3 & 6,0 & 5,5 \\
\hline Portugal & 8,2 & 6,9 & 6,0 & 6,2 & 6,1 & 6,3 & 6,0 & 6,4 & 6,7 & 6,8 & 7,0 & 7,1 \\
\hline Romania & & & & & & & 5,2 & 4,1 & 4,0 & 3,4 & 3,4 & 3,6 \\
\hline Slovakia * & 8,3 & 6,7 & 6,3 & 7,6 & 8,9 & 7,6 & 7,2 & 5,4 & 5,6 & 6,1 & 4,8 & 3,7 \\
\hline Slovenia & & & & & 6,7 & 7,7 & 7,0 & 6,6 & 6,5 & 6,4 & 6,1 & 6,2 \\
\hline Sweden & 10,6 & 11,0 & 10,2 & 9,5 & 9,5 & 8,2 & 8,7 & 7,8 & 7,5 & 7,6 & 7,7 & 7,5 \\
\hline Czech Republic & 4,3 & 4,3 & 4,0 & 4,2 & 4,1 & 4,3 & 4,8 & 5,2 & 4,9 & 5,4 & 4,4 & 4,4 \\
\hline Finland & 8,3 & 8,4 & 7,7 & 7,4 & 7,0 & 6,9 & 6,6 & 6,7 & 6,7 & 6,8 & 6,5 & 6,2 \\
\hline EU - 27 & & & & & & & 6,6 & 6,6 & 6,4 & 6,4 & 6,2 & 6,1 \\
\hline
\end{tabular}

Source: Eurostat

* Estimations 
Table 3. Defense expenditure ( $\%$ of GDP)

\begin{tabular}{|c|c|c|c|c|c|c|c|c|c|c|c|c|}
\hline & 1996 & 1997 & 1998 & 1999 & 2000 & 2001 & 2002 & 2003 & 2004 & 2005 & 2006 & 2007 \\
\hline Austria & 1,0 & 1,0 & 1,0 & 0,9 & 1,0 & 0,9 & 0,9 & 0,9 & 0,9 & 0,9 & 0,8 & 0,9 \\
\hline Belgium & 1,4 & 1,4 & 1,3 & 1,3 & 1,2 & 1,2 & 1,2 & 1,2 & 1,1 & 1,1 & 1,0 & 1,0 \\
\hline Bulgaria & & & & & 4,8 & 2,8 & 4,6 & 2,6 & 1,9 & 2,2 & 1,7 & 1,6 \\
\hline France & 2,6 & 2,4 & 2,3 & 2,2 & 2,1 & 2,1 & 2,1 & 1,9 & 1,9 & 1,9 & 1,8 & 1,8 \\
\hline Germany & 1,3 & 1,3 & 1,2 & 1,3 & 1,1 & 1,1 & 1,1 & 1,1 & 1,0 & 1,0 & 1,0 & 1,0 \\
\hline Denmark & 1,8 & 1,7 & 1,7 & 1,7 & 1,6 & 1,6 & 1,6 & 1,6 & 1,6 & 1,5 & 1,6 & 1,6 \\
\hline Greece & 1,9 & 2,1 & 2,3 & 3,1 & 4,0 & 3,3 & 3,5 & 3,1 & 2,8 & 2,5 & 2,1 & 2,3 \\
\hline Estonia & 1,3 & 1,3 & 1,3 & 1,2 & 1,4 & 1,4 & 1,4 & 1,7 & 1,3 & 1,4 & 1,3 & 1,3 \\
\hline $\begin{array}{l}\text { United } \\
\text { Kingdom }\end{array}$ & 2,8 & 2,8 & 2,6 & 2,4 & 2,5 & 2,3 & 2,4 & 2,5 & 2,5 & 2,4 & 2,6 & 2,4 \\
\hline Ireland & 0,9 & 0,9 & 0,8 & 0,7 & 0,7 & 0,7 & 0,6 & 0,5 & 0,6 & 0,5 & 0,5 & 0,5 \\
\hline Spain & 1,3 & 1,3 & 1,2 & 1,1 & 1,1 & 1,1 & 1,1 & 1,1 & 1,1 & 1,1 & 1,0 & 1,0 \\
\hline Italy & 1,1 & 1,0 & 1,0 & 1,1 & 1,1 & 1,1 & 1,2 & 1,4 & 1,4 & 1,4 & 1,3 & 1,3 \\
\hline Cyprus & & & 1,8 & 2,0 & 1,7 & 1,9 & 2,1 & 2,2 & 1,8 & 1,9 & 2,0 & 1,8 \\
\hline Latvia & 1,0 & 0,9 & 0,8 & 1,0 & 1,0 & 1,0 & 1,2 & 1,2 & 1,3 & 1,4 & 1,6 & 1,5 \\
\hline Lithuania & & & & & 1,3 & 1,3 & 1,5 & 1,4 & 1,4 & 1,4 & 1,6 & 1,9 \\
\hline Luxembourg & 0,6 & 0,6 & 0,5 & 0,3 & 0,3 & 0,3 & 0,3 & 0,3 & 0,3 & 0,2 & 0,2 & 0,2 \\
\hline Malta & 1,0 & 0,9 & 0,8 & 0,8 & 0,7 & 0,8 & 0,7 & 0,9 & 1,0 & 0,9 & 0,8 & 0,7 \\
\hline Holland & 1,9 & 1,7 & 1,6 & 1,6 & 1,6 & 1,6 & 1,5 & 1,5 & 1,5 & 1,4 & 1,4 & 1,4 \\
\hline Hungary & & & & & & 1,2 & 1,5 & 1,3 & 1,3 & 1,3 & 1,4 & 1,3 \\
\hline Poland & & & & & & & 1,3 & 1,2 & 1,0 & 1,1 & 1,2 & 1,4 \\
\hline Portugal & 1,7 & 1,5 & 1,5 & 1,5 & 1,6 & 1,4 & 1,4 & 1,3 & 1,4 & 1,4 & 1,3 & 1,1 \\
\hline Romania & & & & & & & 2,0 & 2,7 & 2,2 & 2,9 & 2,4 & 2,5 \\
\hline Slovakia * & 2,8 & 2,5 & 2,4 & 2,1 & 2,2 & 2,2 & 2,1 & 1,8 & 1,9 & 1,6 & 1,7 & 1,5 \\
\hline Slovenia & & & & & 1,1 & 1,2 & 1,2 & 1,2 & 1,3 & 1,3 & 1,5 & 1,3 \\
\hline Sweden & 2,5 & 2,4 & 2,4 & 2,4 & 2,3 & 2,2 & 2,1 & 2,0 & 1,9 & 1,7 & 1,7 & 1,6 \\
\hline $\begin{array}{l}\text { Czech } \\
\text { Republic }\end{array}$ & 1,6 & 1,7 & 1,5 & 1,7 & 1,7 & 1,6 & 1,6 & 1,9 & 1,4 & 1,6 & 1,3 & 1,2 \\
\hline Finland & 1,9 & 1,8 & 1,7 & 1,5 & 1,4 & 1,3 & 1,3 & 1,4 & 1,5 & 1,6 & 1,4 & 1,4 \\
\hline EU - 27 & & & & & & & 1,6 & 1,6 & 1,6 & 1,6 & 1,5 & 1,5 \\
\hline
\end{tabular}

Source: Eurostat

* Estimations 
Table 4. Economic affairs expenditure (\% of GDP)

\begin{tabular}{|c|c|c|c|c|c|c|c|c|c|c|c|c|}
\hline & 1996 & 1997 & 1998 & 1999 & 2000 & 2001 & 2002 & 2003 & 2004 & 2005 & 2006 & 2007 \\
\hline Austria & 5,4 & 4,9 & 5,3 & 4,9 & 4,3 & 5,2 & 4,7 & 5,0 & 8,4 & 4,9 & 5,0 & 4,6 \\
\hline Belgium & 4,7 & 4,8 & 4,7 & 5,1 & 4,9 & 4,6 & 4,6 & 5,3 & 4,3 & 7,3 & 5,1 & 5,1 \\
\hline Bulgaria & & & & & 3,5 & 4,2 & 3,7 & 5,5 & 5,0 & 4,8 & 4,6 & 5,0 \\
\hline France & 3,5 & 3,3 & 3,2 & 3,2 & 3,2 & 3,1 & 3,2 & 3,1 & 3,0 & 3,0 & 2,9 & 2,8 \\
\hline Germany & 4,4 & 4,0 & 4,0 & 4,3 & 1,7 & 4,1 & 4,0 & 3,9 & 3,6 & 3,5 & 3,3 & 3,5 \\
\hline Denmark & 4,5 & 4,2 & 4,1 & 4,1 & 3,8 & 3,6 & 3,6 & 3,6 & 3,6 & 3,6 & 3,5 & 3,4 \\
\hline Greece & 4,3 & 5,5 & 5,6 & 5,5 & 5,9 & 5,1 & 4,6 & 5,3 & 6,2 & 4,7 & 4,0 & 4,4 \\
\hline Estonia & 4,1 & 4,0 & 4,7 & 4,4 & 3,8 & 3,7 & 3,7 & 3,5 & 3,8 & 4,0 & 4,6 & 4,5 \\
\hline $\begin{array}{l}\text { United } \\
\text { Kingdom }\end{array}$ & 2,7 & 2,1 & 1,9 & 2,0 & 1,9 & 2,5 & 2,6 & 2,9 & 2,7 & 2,9 & 3,0 & 2,9 \\
\hline Ireland & 5,4 & 5,1 & 4,7 & 4,7 & 4,6 & 5,3 & 4,8 & 4,6 & 4,3 & 4,3 & 4,3 & 4,8 \\
\hline Spain & 4,8 & 4,5 & 4,8 & 4,6 & 4,7 & 4,6 & 4,7 & 4,5 & 5,2 & 4,8 & 4,8 & 4,9 \\
\hline Italy & 4,7 & 3,7 & 4,0 & 4,0 & 2,7 & 4,4 & 4,1 & 4,0 & 3,8 & 3,7 & 4,8 & 4,0 \\
\hline Cyprus & & & 4,7 & 4,3 & 4,8 & 5,1 & 5,1 & 5,7 & 5,1 & 4,8 & 4,7 & 4,3 \\
\hline Latvia & 3,7 & 3,7 & 4,4 & 5,1 & 3,2 & 2,8 & 2,9 & 3,2 & 3,2 & 3,4 & 4,1 & 4,9 \\
\hline Lithuania & & & & & 6,1 & 4,4 & 4,3 & 3,9 & 4,3 & 3,9 & 4,2 & 4,4 \\
\hline Luxembourg & 5,6 & 3,6 & 4,4 & 4,2 & 4,1 & 2,8 & 5,0 & 4,7 & 4,7 & 4,3 & 4,6 & 4,0 \\
\hline Malta & 7,2 & 7,2 & 7,4 & 7,6 & 6,4 & 6,9 & 6,8 & 9,4 & 6,2 & 6,3 & 5,8 & 5,9 \\
\hline Holland & 4,9 & 4,9 & 4,6 & 4,9 & 4,3 & 5,3 & 5,1 & 5,0 & 4,8 & 4,7 & 4,7 & 4,7 \\
\hline Hungary & & & & & & 5,7 & 7,6 & 5,9 & 5,7 & 5,8 & 6,4 & 6,5 \\
\hline Poland & & & & & & & 3,5 & 3,4 & 3,4 & 3,8 & 4,4 & 4,5 \\
\hline Portugal & 5,9 & 6,3 & 6,4 & 5,6 & 5,3 & 5,6 & 4,8 & 4,6 & 4,4 & 4,4 & 3,8 & 3,8 \\
\hline Romania & & & & & & & 4,0 & 5,0 & 5,3 & 5,3 & 6,9 & 6,8 \\
\hline Slovakia * & 11,3 & 9,4 & 7,8 & 9,0 & 11,0 & 6,7 & 6,7 & 4,4 & 4,3 & 3,8 & 3,9 & 4,3 \\
\hline Slovenia & & & & & 5,2 & 4,3 & 4,4 & 4,8 & 4,1 & 4,0 & 3,9 & 4,0 \\
\hline Sweden & 4,8 & 4,5 & 4,5 & 4,8 & 4,1 & 4,3 & 4,7 & 4,8 & 4,7 & 5,0 & 4,7 & 4,7 \\
\hline Czech Republic & 7,7 & 8,6 & 9,5 & 8,3 & 7,3 & 9,4 & 8,9 & 8,3 & 7,5 & 6,9 & 7,1 & 6,9 \\
\hline Finland & 6,8 & 5,5 & 5,3 & 5,5 & 4,7 & 4,6 & 4,9 & 4,7 & 4,7 & 4,7 & 4,6 & 4,4 \\
\hline EU - 27 & & & & & & & 3,9 & 3,9 & 3,9 & 3,8 & 3,9 & 3,9 \\
\hline
\end{tabular}

Source: Eurostat

* Estimations 
Table 5. Health expenditure (\% of GDP)

\begin{tabular}{|c|c|c|c|c|c|c|c|c|c|c|c|c|}
\hline & 1996 & 1997 & 1998 & 1999 & 2000 & 2001 & 2002 & 2003 & 2004 & 2005 & 2006 & 2007 \\
\hline Austria & 7,7 & 8,2 & 8,3 & 8,4 & 8,2 & 6,9 & 7,0 & 7,4 & 7,3 & 7,3 & 7,5 & 7,5 \\
\hline Belgium & 6,5 & 6,1 & 6,2 & 6,3 & 6,3 & 6,5 & 6,5 & 7,1 & 7,1 & 7,1 & 6,9 & 7,0 \\
\hline Bulgaria & & & & & 3,3 & 2,5 & 4,5 & 5,1 & 6,6 & 6,7 & 4,2 & 3,1 \\
\hline France & 6,7 & 6,6 & 6,6 & 6,6 & 6,6 & 6,7 & 7,0 & 7,2 & 7,3 & 7,3 & 7,2 & 7,2 \\
\hline Germany & 6,4 & 6,2 & 6,1 & 6,2 & 6,3 & 6,4 & 6,5 & 6,6 & 6,3 & 6,4 & 6,3 & 6,3 \\
\hline Denmark & 6,9 & 6,8 & 6,9 & 6,8 & 6,6 & 6,8 & 7,0 & 7,0 & 7,0 & 7,1 & 7,1 & 7,3 \\
\hline Greece & 3,9 & 3,8 & 3,9 & 4,0 & 3,9 & 4,6 & 4,5 & 4,7 & 4,6 & 4,9 & 5,0 & 4,9 \\
\hline Estonia & 4,9 & 4,4 & 4,5 & 4,9 & 4,3 & 4,1 & 4,2 & 4,1 & 4,2 & 4,1 & 4,3 & 4,5 \\
\hline $\begin{array}{l}\text { United } \\
\text { Kingdom }\end{array}$ & 5,7 & 5,4 & 5,4 & 5,6 & 5,7 & 5,9 & 6,2 & 6,3 & 6,8 & 6,9 & 7,2 & 7,5 \\
\hline Ireland & 5,9 & 5,9 & 5,7 & 5,6 & 5,6 & 6,3 & 6,6 & 6,9 & 7,2 & 7,2 & 6,9 & 7,0 \\
\hline Spain & 5,4 & 5,2 & 5,2 & 5,2 & 5,2 & 5,1 & 5,2 & 5,2 & 5,5 & 5,7 & 5,7 & 5,7 \\
\hline Italy & 5,5 & 5,5 & 5,6 & 5,7 & 6,0 & 6,3 & 6,3 & 6,3 & 6,7 & 6,9 & 7,0 & 6,8 \\
\hline Cyprus & & & 2,7 & 2,8 & 2,6 & 2,8 & 3,1 & 3,4 & 3,1 & 3,0 & 3,1 & 2,9 \\
\hline Latvia & 2,1 & 2,3 & 2,2 & 2,7 & 3,3 & 3,5 & 4,3 & 4,4 & 4,2 & 3,9 & 3,9 & 4,6 \\
\hline Lithuania & & & & & 4,1 & 4,7 & 4,3 & 4,3 & 4,2 & 4,9 & 4,6 & 4,6 \\
\hline Luxembourg & 5,2 & 5,0 & 4,8 & 4,4 & 4,1 & 4,8 & 4,7 & 4,8 & 5,0 & 5,1 & 4,6 & 4,5 \\
\hline Malta & 4,3 & 4,6 & 4,6 & 4,6 & 4,9 & 5,2 & 5,8 & 6,0 & 6,1 & 6,4 & 6,4 & 5,8 \\
\hline Holland & 3,4 & 3,8 & 3,8 & 3,7 & 3,7 & 3,9 & 4,2 & 4,4 & 4,4 & 4,4 & 5,7 & 5,7 \\
\hline Hungary & & & & & & 4,9 & 5,5 & 5,7 & 5,5 & 5,6 & 5,6 & 4,9 \\
\hline Poland & & & & & & & 4,4 & 4,3 & 4,2 & 4,4 & 4,6 & 4,6 \\
\hline Portugal & 5,8 & 5,9 & 6,2 & 6,2 & 6,4 & 6,6 & 6,7 & 6,9 & 7,1 & 7,3 & 7,1 & 6,8 \\
\hline Romania & & & & & & & 4,9 & 3,5 & 3,7 & 3,7 & 3,7 & 4,3 \\
\hline Slovakia * & 5,4 & 5,6 & 5,5 & 5,2 & 5,1 & 5,0 & 5,1 & 2,9 & 4,8 & 5,0 & 6,0 & 6,5 \\
\hline Slovenia & & & & & 6,4 & 6,7 & 6,6 & 6,5 & 6,2 & 6,1 & 6,0 & 5,9 \\
\hline Sweden & 6,5 & 6,3 & 6,2 & 6,3 & 6,2 & 6,6 & 6,9 & 7,1 & 6,8 & 6,8 & 6,8 & 6,8 \\
\hline Czech Republic & 6,3 & 5,8 & 5,8 & 5,9 & 5,7 & 6,0 & 6,2 & 6,4 & 7,3 & 7,2 & 7,2 & 7,1 \\
\hline Finland & 6,4 & 6,2 & 5,9 & 5,8 & 5,7 & 5,8 & 6,2 & 6,5 & 6,6 & 6,9 & 6,8 & 6,6 \\
\hline EU - 27 & & & & & & & 6,2 & 6,3 & 6,4 & 6,5 & 6,6 & 6,6 \\
\hline
\end{tabular}

Source: Eurostat

* Estimations 
Table 6. Education expenditure (\% of GDP)

\begin{tabular}{|c|c|c|c|c|c|c|c|c|c|c|c|c|}
\hline & 1996 & 1997 & 1998 & 1999 & 2000 & 2001 & 2002 & 2003 & 2004 & 2005 & 2006 & 2007 \\
\hline Austria & 6,1 & 6,2 & 6,1 & 6,1 & 5,9 & 5,9 & 5,9 & 6,0 & 5,8 & 5,8 & 5,2 & 5,2 \\
\hline Belgium & 6,1 & 6,0 & 6,0 & 5,9 & 5,7 & 5,8 & 5,9 & 6,0 & 5,9 & 6,0 & 5,8 & 5,8 \\
\hline Bulgaria & & & & & 4,4 & 3,8 & 3,9 & 4,4 & 4,2 & 4,1 & 3,9 & 3,9 \\
\hline France & 6,5 & 6,5 & 6,4 & 6,6 & 6,3 & 6,3 & 6,4 & 6,4 & 6,2 & 6,1 & 6,0 & 5,9 \\
\hline Germany & 4,4 & 4,4 & 4,3 & 4,3 & 4,0 & 4,2 & 4,2 & 4,1 & 4,1 & 4,1 & 4,0 & 3,9 \\
\hline Denmark & 7,5 & 7,3 & 7,6 & 8,1 & 8,0 & 8,1 & 8,2 & 8,2 & 8,2 & 8,0 & 7,7 & 7,4 \\
\hline Greece & 2,5 & 2,8 & 2,8 & 2,8 & 2,9 & 2,7 & 2,9 & 3,2 & 3,1 & 3,0 & 2,9 & 3,0 \\
\hline Estonia & 7,4 & 7,0 & 7,3 & 7,5 & 6,7 & 6,7 & 6,8 & 6,6 & 6,3 & 6,1 & 6,2 & 6,2 \\
\hline $\begin{array}{l}\text { United } \\
\text { Kingdom }\end{array}$ & 4,7 & 4,6 & 4,5 & 4,7 & 5,0 & 5,3 & 5,6 & 5,8 & 5,9 & 6,1 & 6,1 & 6,2 \\
\hline Ireland & 4,9 & 4,7 & 4,2 & 4,1 & 4,2 & 4,3 & 4,3 & 4,4 & 4,4 & 4,4 & 4,4 & 4,5 \\
\hline Spain & 4,6 & 4,5 & 4,4 & 4,4 & 4,4 & 4,3 & 4,4 & 4,4 & 4,4 & 4,3 & 4,3 & 4,4 \\
\hline Italy & 4,9 & 4,8 & 4,8 & 4,7 & 4,6 & 4,7 & 4,7 & 4,9 & 4,6 & 4,7 & 4,6 & 4,7 \\
\hline Cyprus & & & 6,0 & 6,0 & 6,0 & 6,1 & 6,5 & 7,6 & 7,1 & 7,2 & 7,2 & 7,4 \\
\hline Latvia & 5,2 & 5,4 & 5,7 & 5,7 & 5,5 & 5,4 & 5,3 & 5,2 & 5,6 & 5,4 & 5,5 & 5,8 \\
\hline Lithuania & & & & & 6,0 & 6,0 & 6,1 & 5,7 & 5,8 & 5,5 & 5,4 & 5,2 \\
\hline Luxembourg & 4,5 & 4,7 & 4,9 & 4,6 & 4,3 & 4,6 & 4,8 & 4,9 & 5,1 & 4,9 & 4,5 & 4,5 \\
\hline Malta & 5,5 & 5,9 & 5,4 & 5,5 & 5,2 & 5,9 & 6,0 & 6,2 & 5,8 & 5,7 & 5,6 & 5,4 \\
\hline Holland & 5,1 & 4,9 & 4,8 & 4,8 & 4,7 & 4,8 & 5,0 & 5,2 & 5,2 & 5,2 & 5,1 & 5,1 \\
\hline Hungary & & & & & & 5,3 & 5,8 & 6,2 & 5,8 & 5,9 & 5,8 & 5,3 \\
\hline Poland & & & & & & & 6,1 & 6,1 & 5,7 & 6,1 & 6,0 & 5,7 \\
\hline Portugal & 6,4 & 6,3 & 6,3 & 7,2 & 6,7 & 6,9 & 7,3 & 7,4 & 7,4 & 7,6 & 7,1 & 5,8 \\
\hline Romania & & & & & & & 4,0 & 3,5 & 3,7 & 3,6 & 4,1 & 4,2 \\
\hline Slovakia * & 3,8 & 3,8 & 3,6 & 3,3 & 3,2 & 3,3 & 3,6 & 4,3 & 3,9 & 4,0 & 3,9 & 4,0 \\
\hline Slovenia & & & & & 6,3 & 6,4 & 6,3 & 6,4 & 6,3 & 6,4 & 6,3 & 5,8 \\
\hline Sweden & 7,0 & 7,1 & 7,4 & 7,5 & 6,8 & 7,2 & 7,3 & 7,3 & 7,1 & 7,1 & 7,0 & 6,9 \\
\hline Czech Republic & 4,1 & 4,3 & 4,0 & 4,0 & 4,1 & 4,4 & 5,2 & 5,2 & 4,8 & 4,8 & 4,9 & 4,7 \\
\hline Finland & 6,9 & 6,5 & 6,2 & 6,1 & 5,9 & 6,0 & 6,1 & 6,4 & 6,3 & 6,2 & 6,0 & 5,8 \\
\hline EU - 27 & & & & & & & 5,3 & 5,3 & 5,2 & 5,3 & 5,2 & 5,1 \\
\hline
\end{tabular}

Source: Eurostat

* Estimations 
Table 7. Social protection expenditure (\% of GDP)

\begin{tabular}{|c|c|c|c|c|c|c|c|c|c|c|c|c|}
\hline & 1996 & 1997 & 1998 & 1999 & 2000 & 2001 & 2002 & 2003 & 2004 & 2005 & 2006 & 2007 \\
\hline Austria & 21,8 & 21,4 & 21,2 & 21,4 & 21,1 & 21,0 & 21,2 & 21,4 & 21,0 & 20,6 & 20,3 & 19,9 \\
\hline Belgium & 18,1 & 18,0 & 17,6 & 17,3 & 16,8 & 17,0 & 17,5 & 17,9 & 17,8 & 17,6 & 17,2 & 17,1 \\
\hline Bulgaria & & & & & 15,0 & 13,3 & 14,4 & 13,5 & 11,3 & 11,1 & 12,2 & 13,1 \\
\hline France & 22,2 & 22,2 & 21,8 & 21,7 & 21,2 & 21,1 & 21,4 & 21,9 & 22,2 & 22,3 & 22,3 & 22,2 \\
\hline Germany & 22,0 & 21,9 & 21,7 & 21,6 & 21,7 & 21,8 & 22,3 & 22,7 & 22,2 & 22,2 & 21,4 & 20,4 \\
\hline Denmark & 24,2 & 23,3 & 23,0 & 22,3 & 21,8 & 22,2 & 22,6 & 23,6 & 23,3 & 22,6 & 22,0 & 21,7 \\
\hline Greece & 15,6 & 15,8 & 16,0 & 16,3 & 17,0 & 17,1 & 17,4 & 17,8 & 17,3 & 17,7 & 17,9 & 18,6 \\
\hline Estonia & 11,6 & 10,8 & 10,9 & 12,0 & 10,8 & 10,2 & 10,0 & 9,9 & 10,2 & 9,9 & 9,6 & 9,8 \\
\hline $\begin{array}{l}\text { United } \\
\text { Kingdom }\end{array}$ & 16,4 & 16,0 & 15,4 & 14,9 & 14,8 & 15,2 & 15,3 & 15,5 & 15,7 & 15,8 & 15,4 & 15,3 \\
\hline Ireland & 11,6 & 10,6 & 9,8 & 10,6 & 7,6 & 8,0 & 8,7 & 8,9 & 9,2 & 9,3 & 9,7 & 10,0 \\
\hline Spain & 14,5 & 14,1 & 13,6 & 13,3 & 13,0 & 12,8 & 13,0 & 12,9 & 13,0 & 12,9 & 12,9 & 13,0 \\
\hline Italy & 17,6 & 18,0 & 17,7 & 17,9 & 17,5 & 17,4 & 17,7 & 18,0 & 18,0 & 18,1 & 18,1 & 18,2 \\
\hline Cyprus & & & 7,7 & 7,8 & 7,9 & 7,9 & 8,7 & 9,5 & 10,0 & 10,7 & 10,4 & 9,9 \\
\hline Latvia & 13,3 & 13,2 & 14,2 & 15,5 & 13,2 & 11,9 & 11,5 & 10,7 & 10,4 & 9,8 & 9,8 & 8,4 \\
\hline Lithuania & & & & & 12,6 & 11,7 & 10,8 & 10,3 & 10,2 & 9,9 & 9,9 & 11,1 \\
\hline Luxembourg & 16,8 & 17,2 & 16,9 & 16,2 & 15,7 & 16,5 & 17,2 & 17,7 & 17,7 & 17,4 & 16,4 & 15,8 \\
\hline Malta & 13,3 & 13,4 & 13,4 & 13,5 & 12,7 & 13,4 & 13,3 & 14,2 & 14,2 & 14,1 & 13,9 & 13,7 \\
\hline Holland & 19,8 & 18,4 & 17,8 & 17,3 & 16,6 & 16,7 & 17,1 & 17,4 & 17,2 & 16,5 & 16,4 & 16,3 \\
\hline Hungary & & & & & & 14,5 & 15,4 & 15,9 & 16,0 & 17,0 & 17,6 & 17,3 \\
\hline Poland & & & & & & & 18,3 & 18,8 & 17,6 & 17,0 & 16,9 & 15,7 \\
\hline Portugal & 12,2 & 12,0 & 12,1 & 12,0 & 12,5 & 12,9 & 13,5 & 14,6 & 15,1 & 15,7 & 15,9 & 17,5 \\
\hline Romania & & & & & & & 10,4 & 9,3 & 9,6 & 9,8 & 9,7 & 9,9 \\
\hline Slovakia * & 15,0 & 14,8 & 14,5 & 14,9 & 14,2 & 14,6 & 14,9 & 16,3 & 12,1 & 13,2 & 12,4 & 10,6 \\
\hline Slovenia & & & & & 17,3 & 17,3 & 17,0 & 17,0 & 17,4 & 17,3 & 16,9 & 15,5 \\
\hline Sweden & 25,6 & 24,4 & 23,1 & 23,5 & 23,2 & 23,3 & 23,4 & 24,3 & 23,9 & 23,4 & 22,7 & 21,6 \\
\hline Czech Republic & 12,3 & 12,8 & 12,6 & 13,0 & 13,4 & 13,3 & 14,6 & 14,4 & 13,0 & 12,8 & 12,7 & 12,9 \\
\hline Finland & 25,6 & 24,1 & 22,4 & 21,9 & 20,3 & 19,9 & 20,6 & 21,2 & 21,1 & 21,1 & 20,4 & 19,9 \\
\hline EU - 27 & & & & & & & 18,6 & 18,9 & 18,7 & 18,6 & 18,3 & 18,0 \\
\hline
\end{tabular}

Source: Eurostat

* Estimations 
Table 8. Public order and safety expenditure (\% of GDP)

\begin{tabular}{|c|c|c|c|c|c|c|c|c|c|c|c|c|}
\hline & 1996 & 1997 & 1998 & 1999 & 2000 & 2001 & 2002 & 2003 & 2004 & 2005 & 2006 & 2007 \\
\hline Austria & 1,6 & 1,6 & 1,6 & 1,6 & 1,5 & 1,5 & 1,5 & 1,5 & 1,5 & 1,5 & 1,5 & 1,4 \\
\hline Belgium & 1,5 & 1,5 & 1,5 & 1,5 & 1,5 & 1,6 & 1,7 & 1,7 & 1,6 & 1,7 & 1,7 & 1,6 \\
\hline Bulgaria & & & & & 0,8 & 2,8 & 0,8 & 3,1 & 2,9 & 2,8 & 2,6 & 3,1 \\
\hline France & 1,2 & 1,2 & 1,2 & 1,2 & 1,2 & 1,2 & 1,3 & 1,3 & 1,3 & 1,3 & 1,3 & 1,3 \\
\hline Germany & 1,7 & 1,7 & 1,7 & 1,7 & 1,6 & 1,6 & 1,7 & 1,7 & 1,7 & 1,6 & 1,6 & 1,6 \\
\hline Denmark & 1,0 & 1,0 & 1,0 & 1,0 & 0,9 & 1,0 & 1,0 & 1,0 & 1,0 & 1,0 & 1,0 & 1,0 \\
\hline Greece & 0,6 & 0,7 & 0,7 & 0,7 & 0,7 & 1,2 & 1,2 & 1,1 & 1,2 & 1,2 & 1,2 & 1,2 \\
\hline Estonia & 2,8 & 2,7 & 2,7 & 2,9 & 2,7 & 2,4 & 2,5 & 2,4 & 2,2 & 2,2 & 2,1 & 2,3 \\
\hline $\begin{array}{l}\text { United } \\
\text { Kingdom }\end{array}$ & 2,1 & 2,1 & 2,0 & 2,1 & 2,2 & 2,3 & 2,4 & 2,4 & 2,6 & 2,6 & 2,5 & 2,5 \\
\hline Ireland & 1,7 & 1,6 & 1,7 & 1,5 & 1,4 & 1,5 & 1,4 & 1,4 & 1,4 & 1,3 & 1,4 & 1,5 \\
\hline Spain & 1,9 & 1,9 & 1,9 & 1,8 & 1,7 & 1,9 & 1,9 & 1,8 & 1,8 & 1,8 & 1,8 & 1,9 \\
\hline Italy & 2,1 & 2,1 & 2,0 & 2,0 & 2,0 & 1,9 & 1,9 & 1,9 & 1,9 & 1,9 & 1,9 & 1,9 \\
\hline Cyprus & & & 2,0 & 2,0 & 1,9 & 1,9 & 2,0 & 2,3 & 2,2 & 2,1 & 2,2 & 2,1 \\
\hline Latvia & 2,9 & 2,5 & 2,7 & 2,8 & 2,3 & 2,3 & 2,2 & 2,3 & 2,0 & 2,1 & 2,5 & 2,7 \\
\hline Lithuania & & & & & 2,1 & 1,9 & 1,9 & 1,9 & 1,9 & 1,8 & 1,8 & 1,7 \\
\hline Luxembourg & 0,8 & 0,8 & 0,8 & 0,9 & 0,9 & 0,9 & 1,0 & 1,1 & 1,1 & 1,0 & 0,9 & 0,9 \\
\hline Malta & 1,7 & 1,8 & 1,8 & 1,6 & 1,6 & 1,7 & 1,7 & 1,7 & 1,7 & 1,6 & 1,5 & 1,5 \\
\hline Holland & 1,4 & 1,4 & 1,4 & 1,5 & 1,4 & 1,5 & 1,7 & 1,8 & 1,8 & 1,8 & 1,8 & 1,8 \\
\hline Hungary & & & & & & 2,0 & 2,3 & 2,1 & 2,1 & 2,1 & 2,2 & 2,0 \\
\hline Poland & & & & & & & 1,5 & 1,7 & 1,6 & 1,7 & 1,8 & 1,8 \\
\hline Portugal & 1,7 & 1,7 & 1,9 & 1,7 & 1,7 & 1,8 & 1,9 & 2,1 & 2,0 & 2,0 & 1,9 & 1,6 \\
\hline Romania & & & & & & & 2,0 & 2,0 & 1,9 & 2,1 & 2,4 & 2,4 \\
\hline Slovakia * & 3,0 & 3,2 & 3,0 & 2,7 & 2,7 & 2,8 & 2,7 & 1,9 & 2,3 & 2,0 & 2,1 & 2,0 \\
\hline Slovenia & & & & & 1,7 & 1,8 & 1,8 & 1,8 & 1,8 & 1,6 & 1,7 & 1,6 \\
\hline Sweden & 1,4 & 1,3 & 1,4 & 1,4 & 1,3 & 1,3 & 1,4 & 1,4 & 1,3 & 1,3 & 1,3 & 1,3 \\
\hline Czech Republic & 2,5 & 2,4 & 2,2 & 2,4 & 2,4 & 2,2 & 2,1 & 2,2 & 2,2 & 2,2 & 2,2 & 2,1 \\
\hline Finland & 1,5 & 1,4 & 1,4 & 1,4 & 1,4 & 1,3 & 1,3 & 1,4 & 1,3 & 1,4 & 1,3 & 1,2 \\
\hline EU - 27 & & & & & & & 1,7 & 1,8 & 1,8 & 1,8 & 1,8 & 1,8 \\
\hline
\end{tabular}

Source: Eurostat

* Estimations 
Table 9. Housing and community amenities expenditure (\% of GDP)

\begin{tabular}{|c|c|c|c|c|c|c|c|c|c|c|c|c|}
\hline & 1996 & 1997 & 1998 & 1999 & 2000 & 2001 & 2002 & 2003 & 2004 & 2005 & 2006 & 2007 \\
\hline Austria & 1,6 & 0,9 & 0,9 & 0,8 & 0,8 & 0,8 & 0,7 & 0,8 & 0,6 & 0,6 & 0,6 & 0,6 \\
\hline Belgium & 0,4 & 0,3 & 0,4 & 0,4 & 0,4 & 0,3 & 0,3 & 0,3 & 0,4 & 0,4 & 0,4 & 0,4 \\
\hline Bulgaria & & & & & 0,3 & 0,4 & 0,4 & 0,7 & 0,6 & 0,6 & 0,7 & 1,4 \\
\hline France & 1,5 & 1,6 & 1,5 & 1,5 & 1,7 & 1,7 & 1,8 & 1,8 & 1,8 & 1,8 & 1,9 & 1,9 \\
\hline Germany & 0,8 & 0,8 & 0,9 & 1,0 & 1,0 & 1,0 & 1,0 & 1,1 & 1,0 & 1,0 & 0,9 & 0,8 \\
\hline Denmark & 0,6 & 0,6 & 0,6 & 0,7 & 0,7 & 0,7 & 0,7 & 0,7 & 0,6 & 0,6 & 0,5 & 0,6 \\
\hline Greece & 0,4 & 0,3 & 0,4 & 0,5 & 0,4 & 0,4 & 0,4 & 0,4 & 0,4 & 0,4 & 0,4 & 0,4 \\
\hline Estonia & 0,5 & 0,5 & 0,6 & 0,6 & 0,5 & 0,6 & 0,6 & 0,6 & 0,3 & 0,2 & 0,0 & 0,7 \\
\hline $\begin{array}{l}\text { United } \\
\text { Kingdom }\end{array}$ & 1,1 & 0,9 & 0,8 & 0,7 & 0,8 & 0,7 & 0,8 & 1,0 & 1,0 & 1,1 & 1,1 & 1,1 \\
\hline Ireland & 0,9 & 0,9 & 0,8 & 0,9 & 1,6 & 1,8 & 1,9 & 1,4 & 1,4 & 1,7 & 1,8 & 2,0 \\
\hline Spain & 1,0 & 1,0 & 1,1 & 1,1 & 1,2 & 1,0 & 1,1 & 1,1 & 0,8 & 0,9 & 0,8 & 0,9 \\
\hline Italy & 1,0 & 0,9 & 1,0 & 0,9 & 0,9 & 0,8 & 0,1 & 0,7 & 0,7 & 0,7 & 0,7 & 0,7 \\
\hline Cyprus & & & 2,0 & 2,2 & 2,0 & 2,0 & 2,2 & 2,5 & 2,4 & 2,2 & 2,5 & 2,5 \\
\hline Latvia & 0,7 & 0,6 & 0,8 & 0,7 & 0,8 & 0,7 & 1,2 & 0,8 & 0,8 & 0,7 & 0,8 & 1,3 \\
\hline Lithuania & & & & & 0,4 & 0,4 & 0,4 & 0,4 & 0,3 & 0,3 & 0,3 & 0,3 \\
\hline Luxembourg & 0,9 & 0,9 & 0,9 & 0,8 & 0,7 & 0,8 & 1,0 & 0,8 & 0,8 & 0,7 & 0,6 & 0,6 \\
\hline Malta & 2,4 & 2,2 & 2,4 & 1,7 & 1,5 & 1,5 & 1,3 & 1,0 & 0,9 & 0,8 & 0,8 & 0,7 \\
\hline Holland & 1,1 & 0,9 & 1,2 & 1,0 & 1,0 & 1,0 & 1,1 & 1,1 & 1,1 & 1,1 & 1,0 & 0,9 \\
\hline Hungary & & & & & & 0,9 & 0,8 & 0,7 & 0,8 & 0,9 & 1,1 & 1,0 \\
\hline Poland & & & & & & & 1,5 & 1,4 & 1,4 & 1,4 & 1,2 & 1,1 \\
\hline Portugal & 0,7 & 1,0 & 0,9 & 1,0 & 1,0 & 1,0 & 0,9 & 0,7 & 0,6 & 0,7 & 0,6 & 0,5 \\
\hline Romania & & & & & & & 1,8 & 2,7 & 2,3 & 2,1 & 1,5 & 1,5 \\
\hline Slovakia * & 1,7 & 1,0 & 0,8 & 1,1 & 1,2 & 0,8 & 1,0 & 1,1 & 0,8 & 0,8 & 0,7 & 0,8 \\
\hline Slovenia & & & & & 0,6 & 0,6 & 0,5 & 0,5 & 0,5 & 0,5 & 0,6 & 0,5 \\
\hline Sweden & 2,6 & 2,0 & 1,7 & 1,3 & 0,9 & 1,0 & 0,9 & 0,9 & 0,8 & 0,8 & 0,7 & 0,7 \\
\hline $\begin{array}{l}\text { Czech } \\
\text { Republic }\end{array}$ & 1,2 & 1,1 & 1,2 & 1,0 & 1,1 & 1,2 & 0,6 & 1,2 & 1,6 & 1,6 & 1,6 & 1,1 \\
\hline Finland & 0,8 & 0,6 & 0,5 & 0,4 & 0,4 & 0,4 & 0,4 & 0,3 & 0,3 & 0,3 & 0,3 & 0,4 \\
\hline EU - 27 & & & & & & & 1,0 & 1,1 & 1,0 & 1,1 & 1,0 & 1,0 \\
\hline
\end{tabular}

Source: Eurostat

* Estimations 
Table 10. Recreation, culture and religion expenditure (\% of GDP)

\begin{tabular}{|c|c|c|c|c|c|c|c|c|c|c|c|c|}
\hline & 1996 & 1997 & 1998 & 1999 & 2000 & 2001 & 2002 & 2003 & 2004 & 2005 & 2006 & 2007 \\
\hline Austria & 1,0 & 1,0 & 1,0 & 1,0 & 0,9 & 1,0 & 1,0 & 1,0 & 1,0 & 1,0 & 1,0 & 1,0 \\
\hline Belgium & 0,9 & 0,9 & 0,9 & 0,9 & 1,0 & 1,0 & 1,3 & 1,2 & 1,2 & 1,3 & 1,3 & 1,2 \\
\hline Bulgaria & & & & & 0,9 & 0,7 & 0,7 & 0,9 & 0,8 & 0,7 & 0,8 & 0,8 \\
\hline France & 1,1 & 1,1 & 1,1 & 1,2 & 1,1 & 1,2 & 1,3 & 1,4 & 1,4 & 1,5 & 1,5 & 1,5 \\
\hline Germany & 0,8 & 0,7 & 0,7 & 0,7 & 0,9 & 0,8 & 0,8 & 0,8 & 0,8 & 0,7 & 0,7 & 0,7 \\
\hline Denmark & 1,7 & 1,6 & 1,6 & 1,6 & 1,6 & 1,6 & 1,6 & 1,6 & 1,8 & 1,6 & 1,6 & 1,6 \\
\hline Greece & 0,2 & 0,3 & 0,3 & 0,2 & 0,3 & 0,3 & 0,3 & 0,3 & 0,3 & 0,3 & 0,4 & 0,4 \\
\hline Estonia & 2,2 & 2,1 & 2,2 & 2,2 & 1,9 & 2,0 & 2,1 & 2,1 & 2,2 & 2,5 & 2,4 & 2,1 \\
\hline $\begin{array}{l}\text { United } \\
\text { Kingdom }\end{array}$ & 0,9 & 0,8 & 0,9 & 1,0 & 1,0 & 1,0 & 1,1 & 1,1 & 1,0 & 1,1 & 1,1 & 1,1 \\
\hline Ireland & 0,5 & 0,4 & 0,5 & 0,5 & 0,5 & 0,6 & 0,6 & 0,6 & 0,6 & 0,6 & 0,7 & 0,7 \\
\hline Spain & 1,4 & 1,4 & 1,4 & 1,4 & 1,4 & 1,4 & 1,4 & 1,4 & 1,4 & 1,4 & 1,5 & 1,6 \\
\hline Italy & 0,9 & 0,9 & 0,9 & 0,9 & 0,9 & 0,8 & 0,8 & 0,8 & 0,9 & 0,9 & 0,8 & 0,8 \\
\hline Cyprus & & & 0,9 & 0,9 & 0,9 & 1,0 & 1,1 & 1,2 & 1,1 & 1,2 & 1,2 & 1,3 \\
\hline Latvia & 0,7 & 0,7 & 0,9 & 0,9 & 1,0 & 1,1 & 1,3 & 1,2 & 1,2 & 0,9 & 1,0 & 1,9 \\
\hline Lithuania & & & & & 0,9 & 0,8 & 0,9 & 0,8 & 0,8 & 0,9 & 1,0 & 1,0 \\
\hline Luxembourg & 1,6 & 1,7 & 1,7 & 1,8 & 1,6 & 1,7 & 1,8 & 1,9 & 2,1 & 2,2 & 1,7 & 1,9 \\
\hline Malta & 0,6 & 0,5 & 0,4 & 0,6 & 0,6 & 0,6 & 0,6 & 0,7 & 0,7 & 0,7 & 0,6 & 0,6 \\
\hline Holland & 1,2 & 1,1 & 1,1 & 1,1 & 1,4 & 1,4 & 1,5 & 1,5 & 1,5 & 1,4 & 1,4 & 1,3 \\
\hline Hungary & & & & & & 1,6 & 1,8 & 1,8 & 1,8 & 1,6 & 1,7 & 1,5 \\
\hline Poland & & & & & & & 1,1 & 1,0 & 1,0 & 1,0 & 1,1 & 1,1 \\
\hline Portugal & 0,9 & 1,0 & 1,0 & 1,2 & 1,1 & 1,1 & 1,1 & 1,1 & 1,1 & 1,1 & 1,0 & 1,1 \\
\hline Romania & & & & & & & 0,6 & 0,6 & 0,6 & 0,6 & 0,9 & 1,0 \\
\hline Slovakia * & 1,2 & 1,3 & 1,1 & 0,9 & 1,0 & 0,9 & 0,9 & 1,2 & 1,3 & 1,0 & 0,9 & 0,7 \\
\hline Slovenia & & & & & 1,1 & 1,1 & 1,1 & 1,1 & 1,1 & 1,1 & 1,2 & 1,1 \\
\hline Sweden & 1,9 & 1,8 & 1,8 & 1,8 & 1,1 & 1,1 & 1,1 & 1,1 & 1,0 & 1,0 & 1,1 & 1,1 \\
\hline Czech Republic & 1,3 & 1,1 & 1,1 & 1,0 & 1,0 & 1,1 & 1,3 & 1,3 & 1,2 & 1,2 & 1,3 & 1,3 \\
\hline Finland & 1,4 & 1,4 & 1,3 & 1,2 & 1,2 & 1,1 & 1,1 & 1,2 & 1,2 & 1,1 & 1,1 & 1,1 \\
\hline EU - 27 & & & & & & & 1,1 & 1,1 & 1,1 & 1,1 & 1,1 & 1,1 \\
\hline
\end{tabular}

Source: Eurostat

* Estimations 
Table 11. Environmental protection expenditure (\% of GDP)

\begin{tabular}{|c|c|c|c|c|c|c|c|c|c|c|c|c|}
\hline & 1996 & 1997 & 1998 & 1999 & 2000 & 2001 & 2002 & 2003 & 2004 & 2005 & 2006 & 2007 \\
\hline Austria & 1,2 & 0,3 & 0,3 & 0,5 & 0,5 & 0,5 & 0,5 & 0,5 & 0,5 & 0,5 & 0,5 & 0,5 \\
\hline Belgium & 0,7 & 0,7 & 0,7 & 0,7 & 0,8 & 0,8 & 0,8 & 0,7 & 0,7 & 0,6 & 0,6 & 0,6 \\
\hline Bulgaria & & & & & 1,1 & 1,3 & 0,8 & 1,0 & 0,8 & 0,6 & 1,3 & 1,4 \\
\hline France & 0,6 & 0,6 & 0,6 & 0,6 & 0,7 & 0,7 & 0,7 & 0,8 & 0,8 & 0,8 & 0,8 & 0,9 \\
\hline Germany & 0,9 & 0,8 & 0,7 & 0,7 & 0,7 & 0,7 & 0,6 & 0,6 & 0,6 & 0,6 & 0,6 & 0,6 \\
\hline Denmark & 0,6 & 0,6 & 0,6 & 0,7 & 0,6 & 0,6 & 0,6 & 0,6 & 0,5 & 0,6 & 0,5 & 0,6 \\
\hline Greece & 0,5 & 0,5 & 0,5 & 0,5 & 0,5 & 0,5 & 0,5 & 0,5 & 0,6 & 0,5 & 0,6 & 0,5 \\
\hline Estonia & 0,6 & 0,7 & 0,7 & 0,7 & 0,6 & 0,7 & 0,7 & 0,7 & 0,7 & 0,9 & 0,8 & 0,9 \\
\hline $\begin{array}{l}\text { United } \\
\text { Kingdom }\end{array}$ & 0,5 & 0,5 & 0,5 & 0,6 & 0,6 & 0,7 & 0,7 & 0,7 & 0,7 & 0,6 & 0,9 & 1,0 \\
\hline Ireland & 0,4 & 0,4 & 0,4 & 0,5 & 0,5 & 0,6 & 0,6 & 0,6 & 0,6 & 0,6 & 0,7 & 0,7 \\
\hline Spain & 0,8 & 0,8 & 0,8 & 0,9 & 0,7 & 0,9 & 0,9 & 0,9 & 0,9 & 0,9 & 0,9 & 0,9 \\
\hline Italy & 0,8 & 0,8 & 0,8 & 0,8 & 0,8 & 0,9 & 0,9 & 0,9 & 0,9 & 0,9 & 0,8 & 0,8 \\
\hline Cyprus & & & 0,2 & 0,2 & 0,2 & 0,3 & 0,3 & 0,3 & 0,3 & 0,3 & 0,3 & 0,3 \\
\hline Latvia & 0,5 & 0,3 & 0,5 & 0,9 & 1,0 & 1,0 & 0,4 & 0,4 & 0,6 & 0,9 & 1,1 & 0,6 \\
\hline Lithuania & & & & & 0,1 & 0,1 & 0,1 & 0,1 & 0,4 & 0,6 & 0,8 & 0,9 \\
\hline Luxembourg & 1,3 & 1,3 & 1,3 & 1,2 & 1,1 & 1,2 & 1,1 & 1,1 & 1,1 & 1,1 & 1,0 & 1,0 \\
\hline Malta & 1,4 & 1,1 & 1,1 & 0,9 & 0,8 & 0,9 & 0,7 & 1,4 & 1,4 & 1,5 & 1,5 & 1,5 \\
\hline Holland & 0,9 & 0,8 & 0,9 & 0,9 & 0,8 & 0,8 & 0,8 & 0,9 & 0,9 & 0,9 & 0,8 & 0,8 \\
\hline Hungary & & & & & & 0,8 & 0,9 & 0,7 & 0,7 & 0,6 & 0,7 & 0,7 \\
\hline Poland & & & & & & & 0,6 & 0,6 & 0,6 & 0,6 & 0,6 & 0,6 \\
\hline Portugal & 0,6 & 0,6 & 0,6 & 0,7 & 0,7 & 0,7 & 0,7 & 0,6 & 0,6 & 0,6 & 0,5 & 0,5 \\
\hline Romania & & & & & & & 0,1 & 0,2 & 0,1 & 0,1 & 0,3 & 0,4 \\
\hline Slovakia * & 1,3 & 0,9 & 0,8 & 1,1 & 1,4 & 0,7 & 0,9 & 0,7 & 0,7 & 0,7 & 0,7 & 0,6 \\
\hline Slovenia & & & & & 0,4 & 0,5 & 0,5 & 0,6 & 0,6 & 0,5 & 0,4 & 0,4 \\
\hline Sweden & 0,2 & 0,2 & 0,2 & 0,2 & 0,3 & 0,3 & 0,3 & 0,3 & 0,3 & 0,4 & 0,4 & 0,4 \\
\hline $\begin{array}{l}\text { Czech } \\
\text { Republic }\end{array}$ & 1,2 & 1,1 & 1,1 & 0,9 & 0,9 & 1,0 & 1,0 & 1,2 & 1,1 & 1,2 & 1,2 & 1,0 \\
\hline Finland & 0,3 & 0,3 & 0,3 & 0,3 & 0,3 & 0,3 & 0,3 & 0,3 & 0,3 & 0,3 & 0,3 & 0,3 \\
\hline EU - 27 & & & & & & & 0,7 & 0,7 & 0,7 & 0,7 & 0,7 & 0,7 \\
\hline
\end{tabular}

Source: Eurostat

* Estimations 
Table 12. GDP growth (\% over previous year)

\begin{tabular}{|c|c|c|c|c|c|c|c|c|c|c|c|c|}
\hline & 1996 & 1997 & 1998 & 1999 & 2000 & 2001 & 2002 & 2003 & 2004 & 2005 & 2006 & 2007 \\
\hline Austria & 2,2 & 2,1 & 3,6 & 3,3 & 3,7 & 0,5 & 1,6 & 0,8 & 2,5 & 2,9 & 3,4 & 3,1 \\
\hline Belgium & 1,1 & 3,5 & 1,8 & 3,3 & 3,9 & 0,9 & 1,4 & 1,0 & 2,7 & 2,0 & 2,9 & 2,8 \\
\hline Bulgaria & $-8,0$ & $-5,8$ & 4,1 & 2,3 & 5,4 & 4,1 & 4,5 & 5,0 & 6,6 & 6,2 & 6,3 & 6,2 \\
\hline France & 1,1 & 2,2 & 3,5 & 3,3 & 3,9 & 1,9 & 1,0 & 1,1 & 2,5 & 1,9 & 2,2 & 2,2 \\
\hline Germany & 1,0 & 1,7 & 2,0 & 1,9 & 3,2 & 1,2 & 0,0 & $-0,2$ & 1,2 & 0,8 & 3,0 & 2,5 \\
\hline Denmark & 2,8 & 3,2 & 2,2 & 2,6 & 3,5 & 0,7 & 0,5 & 0,4 & 2,3 & 2,5 & 3,9 & 1,7 \\
\hline Greece & 2,4 & 3,6 & 3,4 & 3,4 & 4,5 & 4,5 & 3,9 & 5,0 & 4,6 & 3,8 & 4,2 & 4,0 \\
\hline Estonia & 5,0 & 10,8 & 5,4 & $-0,1$ & 9,6 & 7,7 & 7,8 & 7,1 & 7,5 & 9,2 & 10,4 & 6,3 \\
\hline United Kingdom & 2,9 & 3,3 & 3,6 & 3,5 & 3,9 & 2,5 & 2,1 & 2,8 & 2,8 & 2,1 & 2,8 & 3,0 \\
\hline Ireland & 8,1 & 11,5 & 8,4 & 10,7 & 9,2 & 5,8 & 6,4 & 4,5 & 4,7 & 6,4 & 5,7 & 6,0 \\
\hline Spain & 2,4 & 3,9 & 4,5 & 4,7 & 5,1 & 3,6 & 2,7 & 3,1 & 3,3 & 3,6 & 3,9 & 3,7 \\
\hline Italy & 1,1 & 1,9 & 1,4 & 1,5 & 3,7 & 1,8 & 0,5 & 0,0 & 1,5 & 0,6 & 1,8 & 1,5 \\
\hline Cyprus & 1,8 & 2,3 & 5,0 & 4,8 & 5,0 & 4,0 & 2,1 & 1,9 & 4,2 & 3,9 & 4,0 & 4,4 \\
\hline Latvia & 3,9 & 8,4 & 4,7 & 3,3 & 6,9 & 8,0 & 6,5 & 7,2 & 8,7 & 10,6 & 12,2 & 10,3 \\
\hline Lithuania & 5,1 & 8,5 & 7,5 & $-1,5$ & 4,1 & 6,6 & 6,9 & 10,3 & 7,3 & 7,9 & 7,9 & 8,9 \\
\hline Luxembourg & 1,5 & 5,9 & 6,5 & 8,4 & 4,4 & 2,5 & 4,1 & 2,1 & 4,9 & 5,0 & 6,1 & 4,5 \\
\hline Malta & & & & & & $-1,6$ & 2,6 & $-0,3$ & 1,1 & 3,5 & 3,1 & 3,7 \\
\hline Holland & 3,4 & 4,3 & 3,9 & 4,7 & 3,9 & 1,9 & 0,1 & 0,3 & 2,2 & 2,0 & 3,4 & 3,5 \\
\hline Hungary & 1,3 & 4,6 & 4,9 & 4,2 & 5,2 & 4,1 & 4,4 & 4,2 & 4,8 & 4,1 & 3,9 & 1,3 \\
\hline Poland & 6,2 & 7,1 & 5,0 & 4,5 & 4,3 & 1,2 & 1,4 & 3,9 & 5,3 & 3,6 & 6,2 & 6,6 \\
\hline Portugal & 3,6 & 4,2 & 4,9 & 3,8 & 3,9 & 2,0 & 0,8 & $-0,8$ & 1,5 & 0,9 & 1,4 & 1,9 \\
\hline Romania & 3,9 & $-6,1$ & $-4,8$ & $-1,2$ & 2,1 & 5,7 & 5,1 & 5,2 & 8,5 & 4,2 & 7,9 & 6,0 \\
\hline Slovakia * & 6,1 & 4,6 & 4,4 & 0,0 & 1,4 & 3,4 & 4,8 & 4,8 & 5,2 & 6,6 & 8,5 & 10,4 \\
\hline Slovenia & 3,7 & 4,8 & 3,9 & 5,4 & 4,1 & 3,1 & 3,7 & 2,8 & 4,4 & 4,1 & 5,7 & 6,1 \\
\hline Sweden & 1,5 & 2,5 & 3,8 & 4,6 & 4,4 & 1,1 & 2,4 & 1,9 & 4,1 & 3,3 & 4,1 & 2,7 \\
\hline Czech Republic & 4,2 & $-0,7$ & $-0,8$ & 1,3 & 3,6 & 2,5 & 1,9 & 3,6 & 4,5 & 6,3 & 6,8 & 6,6 \\
\hline Finland & 3,7 & 6,1 & 5,2 & 3,9 & 5,0 & 2,6 & 1,6 & 1,8 & 3,7 & 2,8 & 4,9 & 4,5 \\
\hline EU - 27 & & & & 3,0 & 3,9 & 2,0 & 1,2 & 1,3 & 2,5 & 2,0 & 3,1 & 2,9 \\
\hline
\end{tabular}

Sources: IMF, Eurostat

*Estimations 


\title{
Management of Educational Records in Nigerian Universities for Better Results
}

\author{
Chika Josephine Ifedili (Phd) \& Jennifer Jomafuvwe Agbaire (Mrs) \\ Faculty of Education, University of Benin \\ P.O. Box 10073, Ugbowo, Benin City, Edo State, Nigeria \\ E-mail: theifedilis@yahoo.com
}

$\begin{array}{lrr}\text { Received: July 23, } 2011 & \text { Accepted: August 24, } 2011 & \text { Published: December 1, } 2011 \\ \text { doi:10.5539/res.v3n2p52 } & \text { URL: http://dx.doi.org/10.5539/res.v3n2p52 }\end{array}$

\begin{abstract}
The paper investigated the status of record-keeping in Nigerian universities following the general complaints by graduated students, retired staff etc that the record-keeping in Nigerian universities was below standard. The population of the study consisted of all academic and non-academic staff of 114 universities in the six geo-political zones of the federation of Nigeria: North-Central, Northeast, Northwest, Southeast, South-south and Southwest. A sample of 150 academic staff and 150 non-academic staff were selected by stratified random sampling method from each geographical zones of the federation. A total sample of 900 academic staff (485 males and 415 females) and 900 non-academic staff (452 males and 448 females) participated in the study. The data of the study was collected using questionnaire. The questionnaire was titled University Record Keeping Inventory (URKI). The validity of the questionnaire was done by experts in Educational Administration and Planning. The reliability of the instrument was tested using a Split-Half Method. The correlation coefficient was corrected by the use of Spearman Brown Formula. The Pearson Product Moment Correlation was .77 and the final Spearman Brown Formula yielded 0.87. The statistics used were Z-test and simple percentage. The major finding was that record-keeping in Nigerian Universities was below average. Based on the finding, it was recommended that University administrators should train their personnel and update their record-keeping facilities to reflect what is obtainable in global villages.
\end{abstract}

Keywords: Management, Records, Educational, Universities, Nigeria

\section{Introduction}

Every existing organization functions through a flow of information concerning various aspects that make it up facilities, funds, personnel and so on. Records refer to information or data on any such specific subject obtained and preserved for future reference or use. For a piece of information to be considered a record however, it must meet such parameters as genuineness and authenticity (Egwuyenga, 2005). To put it differently, the information must not only be original in its details but also correct and true. Records management on the other hand, involves the effective, efficient and systematic control of the processes of creating, receiving, maintaining, and disposing valuable information about the organization. It is the means of processing information for optimum accessibility and usability, concerned with the origination, collection, organization, storage, retrieval, interpretation, transmission, transformation and use (Vakkari and Cronin, 1992).

Suffice it to say that the planning, coordinating, organizing, controlling and implementing of school activities, particularly tertiary institutions, would be a leap in the dark in the absence of accurate and accessible records that will be made possible through an effective record-keeping practice. Educational records are kept for purposes which range from documenting evidence of every significant activity undertaken in the school system to ensuring a smooth connection between the past, present and future operations of the system, the overall essence of which is to make the right information available to the right person in the right order at the right place and time with the most minimal of costs. There has been series of complaints by lecturers, students, guardians, parents and other educational stakeholders that record-keeping in Nigerian universities is very porous, time-consuming and the records are at times, not available. If the university organization is to perform well, there is need for properly kept records as these will make the management efficient and effective. 